\section{Development of vulnerability framework for assessing the air pollution-related health impacts in four districts of Delhi, India}

\author{
Anoop Raj Singh ${ }^{*, *}$ and Neha Oli ${ }^{\#}$ \\ The Energy and Resources Institute, School of Advance Studies, \\ Plot No. 10, Institutional Area, Vasant Kunj, New Delhi 110 070, India
}

Air pollution and its deleterious public health risks are a major concern across the world. It is one of the leading health risk factors causing high mortality and disease burden in many cities. Epidemiological risk assessment studies have generated considerable evidence of disease burden due to air pollution. Such evidence proves useful as inputs for framing various air quality management and public health protection policies. Implementation of these policies also necessitates a critical insight from a perspective of differential population vulnerability to air pollution. Hence, the present study proposes a methodological approach for developing an integrated vulnerability assessment framework that focuses on multidimensional aspects adhering to vulnerability in nexus with health risk characterization. The designed framework has been applied in a pilot case study undertaken in four districts of Delhi, India. Weightage has been multiplied by a normalized score for each indicator to calculate the vulnerability score. The score reflects relative vulnerability level based on the components - emission load, exposure, land use-land cover features, sensitivity and coping capacity. Findings of the study have shown maximum score for East Delhi and minimum score for New Delhi. Hence the study throws light on the factors that are contributing towards the vulnerability of human health to air pollution.

Keywords: Coping capacity, emission load, exposure, land use-land cover, sensitivity.

AIR pollution has gained critical status by posing a global health risk $^{1}$, and has been ranked as the fourth leading risk factor for deaths globally ${ }^{2}$. The severity and complexity of the effect of air pollution on human health increase several-fold when coupled with other variables. For instance, $85 \%$ of the world's population is found to live in areas above the permissible limit $\left(10 \mu \mathrm{g} / \mathrm{m}^{3}\right)$ of $\mathrm{PM}_{2.5}$ (annual mean) set by the World Health Organization $(\mathrm{WHO})^{2}$. Additionally, urban areas of developing nations like India encounter frequent air pollution episodes because of unprecedented growth in many sectors, such as, power generation, transport, solid waste generation and industries which further cause environmental and health concerns ${ }^{1,3-5}$. These episodes may cause instant

\footnotetext{
*For correspondence. (e-mail: anooprajsingh23@gmail.com)
}

"Equally contributed. illnesses (acute disease) or may add to existing air pollution-related health complexities (chronic disease) to an individual $^{6}$. Also, these air pollution-related health challenges are linked to time-varying exposures to both indoor and/or ambient air pollutants. However, the impact of indoor air on human health is rarely taken into consideration, despite the fact that $90 \%$ of our time is spent in an indoor environment ${ }^{7}$.

The menace of air pollution is aggravated in Indian cities $^{1,8}$, which can be deduced from the fact that every year Indian megacities (Delhi, Mumbai and Kolkata) are making the list of twenty most polluted cities/towns of the world ${ }^{5,9}$. Therefore, various health impact assessment studies due to air pollution in the national capital of India have been undertaken, which report epidemiological evidence on the causal association between air pollution and health outcomes such as respiratory and cardiovascular mortality ${ }^{1,6,10-13}$. However, it is also noticed that no framework has been developed to quantify the severity of different parameters (population, land use-land cover, hospital facility, homeless population, etc.) together with air pollution, on human health.

In the present study, we have assessed the vulnerability of four districts of Delhi due to various factors coupled with air pollution. Vulnerability assessment by analysing multiple factors is a challenging task as it requires an understanding of various disciplines to identify the causal factors supported with logical rationales on their contribution or negation to an individual's vulnerability. Adding to the complexities of vulnerability assessment is the estimation of human exposure to air pollution which fluctuates, as an individual switches from one micro-environment to the other ${ }^{14}$. Therefore, this study aims (1) to design an integrated framework for carrying out a vulnerability assessment of air pollution-related health impacts in Delhi. (2) To calculate vulnerability score for identifying relative vulnerability levels in four districts in Delhi.

The capital of India, New Delhi is located at $28^{\circ} 24^{\prime} 17^{\prime \prime}$ and $28^{\circ} 53^{\prime} 00^{\prime \prime} \mathrm{N}$ lat., $77^{\circ} 45^{\prime} 30^{\prime \prime}$ and $77^{\circ} 21^{\prime} 30^{\prime \prime} \mathrm{E}$ long. For the present study, we selected four districts (Figure 1) of Delhi state, viz. New Delhi (Mandir Marg), North (Civil lines), South West (IGI) and East (Anand Vihar). The selection of district was determined by the presence of air quality monitoring station (information in the parenthesis is the location of monitoring station in the respective district), small population size (Annexure I) and, availability of secondary data for the selected components (viz. land use-land cover, sensitivity, coping capacity) and their respective aforementioned indicators (viz. forested land, construction site, hospital).

To conceptualize the vulnerability framework, indicators were selected primarily by consulting the existing published literature ${ }^{3,5,15-17}$.

For primary data collection, site households were surveyed randomly based on a structured questionnaire with a sample size at a $95 \%$ confidence interval 
RESEARCH COMMUNICATIONS
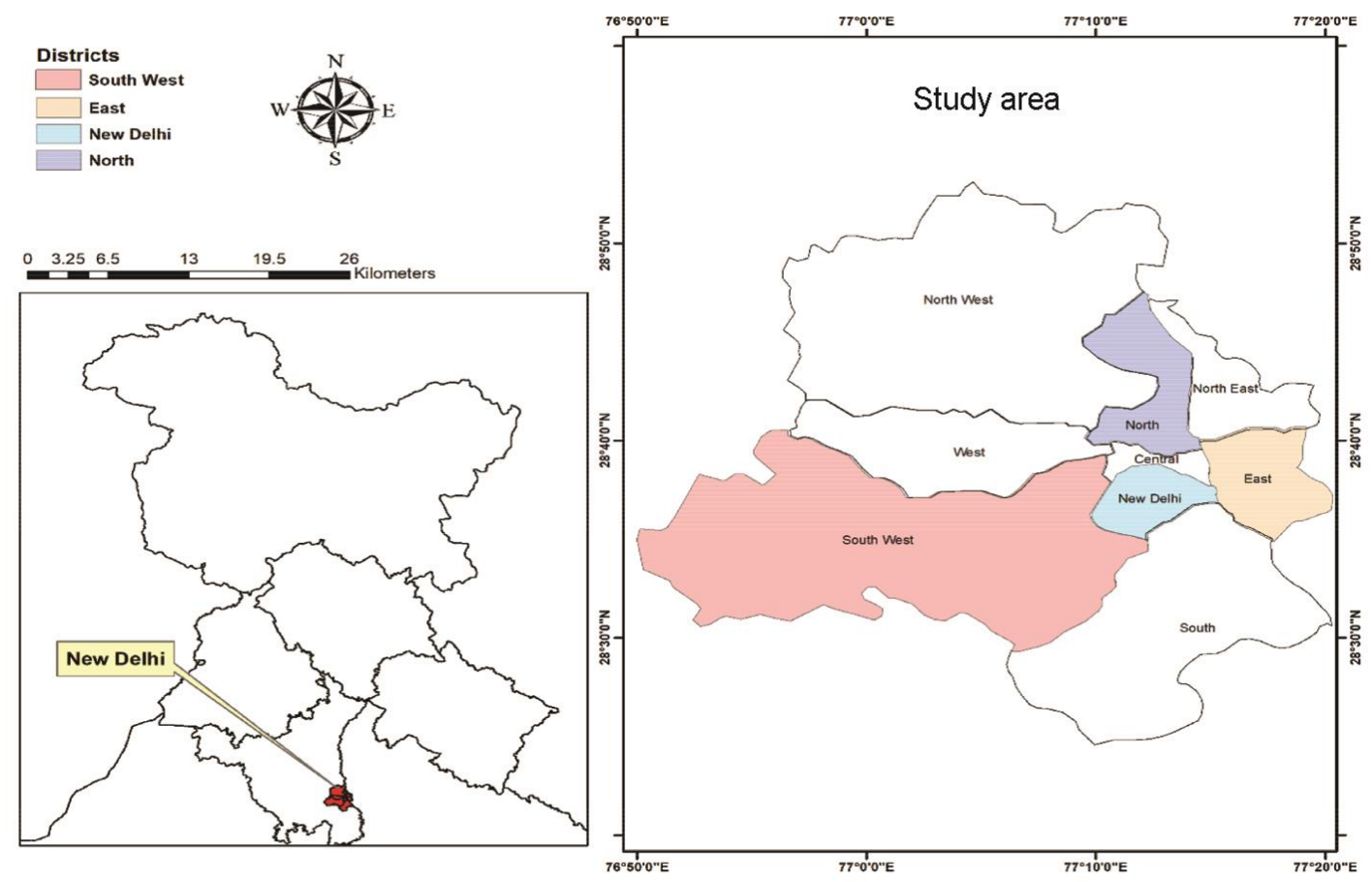

Figure 1. Location of four districts in the study area.

\section{VULNERABILITY FRAMEWORK}

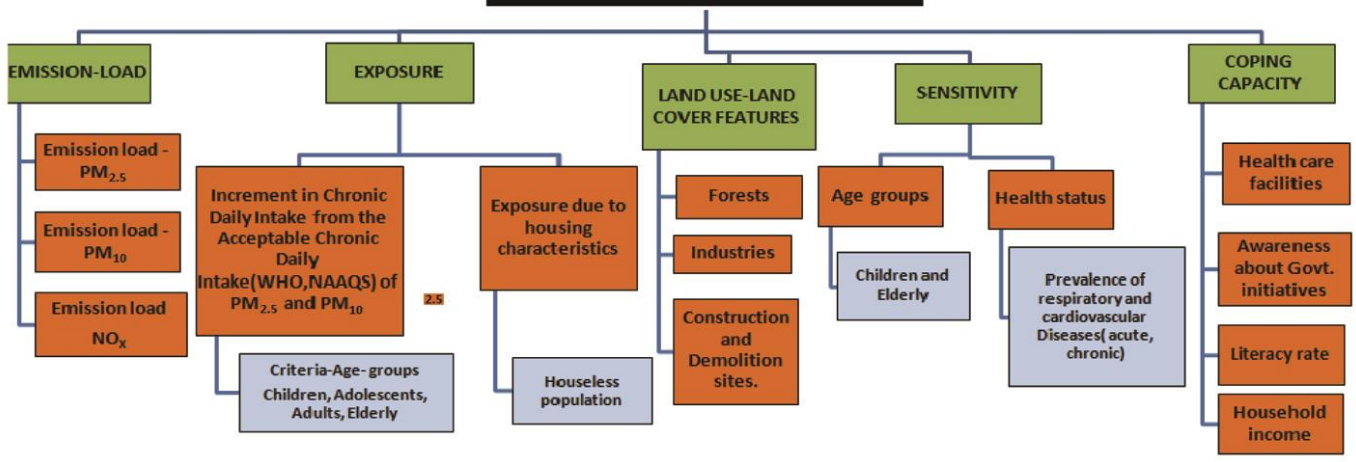

\begin{tabular}{lll|} 
Colour Code: & Component & Indicator \\
\hline
\end{tabular}

Figure 2. Vulnerability framework.

(Supplementary Annexure I). These cross-sectional surveys were conducted in 2016-17, mainly with the volunteering support of post-graduate students. The questionnaire broadly constituted four sections: (1) demographic profile, (2) family details, (3) exposure cycle assessment (hours spent at home, in-transit, workplace and outdoor activities), and (4) awareness of an individual (yes/no) regarding the latest government initiatives to curb air pollution.

Furthermore, indoor and in-transit pollutants concentration data were obtained from secondary sources, and outdoor air pollutant concentration data were directly downloaded from the Central Pollution Control Board (https://cpcb.nic.in/). Data for the emission load component (Figure 2) was taken from a published report ${ }^{18}$ for three criteria pollutants $\mathrm{PM}_{2.5}, \mathrm{PM}_{10}$ and $\mathrm{NO}_{x}$. The data for few other indicators and components (population density, number of hospital beds, etc.) were acquired using several crucial reports, such as Indian Census Statistics ${ }^{19}$, annual report by the Directorate General of Health Statis$\operatorname{tics}^{20}$, air quality guidelines, World Health Organization report $^{21,22}$, National Ambient Air Quality Station 


\section{RESEARCH COMMUNICATIONS}

(NAAQS) notified by $\mathrm{CPCB}^{23}$, Indian State Forest Report $^{24}$ and Exposure Factor Handbook ${ }^{25}$.

Chronic daily intake (mg/kg-day) was calculated for pollutants $\mathrm{PM}_{2.5}, \mathrm{PM}_{10}$ in four age groups - children (311 years), adolescents (11-21 years), adults (21-61 years) and elderly (above 61 years) by using the equation

$$
\mathrm{CDI}=\mathrm{C}\left[\frac{(\mathrm{IR})(\mathrm{EFD})}{(\mathrm{BW})}\right]\left(\frac{1}{\mathrm{AT}}\right) \mathrm{mg} / \mathrm{kg} \text {-day, }
$$

where CDI is the chronic daily intake ( $\mathrm{mg} / \mathrm{kg}$-day), $\mathrm{C}$ the concentration of the pollutant $\left(\mathrm{mg} / \mathrm{m}^{3}\right)$, IR the inhalation rate $\left(\mathrm{m}^{3} /\right.$ day), EFD the exposure frequency and duration (days) and $\mathrm{BW}$ is the body weight $(\mathrm{kg})$. (Note: Inhalation rates $\left(\mathrm{m}^{3} /\right.$ day) and bodyweight $(\mathrm{kg})$ for the above age groups were referred from USEPA ${ }^{25}$ )

$$
\mathrm{CDI}_{\text {Total }}=\left(\mathrm{CDI}_{\mathrm{I}}+\mathrm{CDI}_{\mathrm{O}}+\mathrm{CDI}_{\mathrm{TT}}\right) \mathrm{mg} / \mathrm{kg}-\text { day },
$$

where $\mathrm{CDI}_{\text {Total }}$ is total chronic daily intake by an individual in $24 \mathrm{~h}$ (hereafter referred as $\mathrm{CDI}_{\mathrm{T}}$ ), $\mathrm{CDI}_{\mathrm{I}}$ is the indoor chronic daily intake, $\mathrm{CDI}_{\mathrm{O}}$ the outdoor chronic daily intake, and $\mathrm{CDI}_{\mathrm{TT}}$ is the transit time chronic daily intake

$$
\mathrm{CDI}_{\mathrm{A}}=\mathrm{C}_{\mathrm{REF}}\left(\frac{\mathrm{IR} \times \mathrm{EFD}}{\mathrm{BW} \times \mathrm{AT}}\right) \mathrm{mg} / \mathrm{kg} \text {-day, }
$$

where $\mathrm{CDI}_{\mathrm{A}}$ is the acceptable chronic daily intake values for the reference concentrations $\left(\mathrm{C}_{\mathrm{REF}}\right)$ for pollutants $\mathrm{PM}_{2.5}$ and $\mathrm{PM}_{10}$, calculated as per the air quality guidelines of NAAQS and WHO respectively.

Percent increment in the values of $\mathrm{CDI}_{\mathrm{T}}$ from $\mathrm{CDI}_{\mathrm{A}}$ was then calculated, using the formula

$$
\mathrm{CDI}_{\mathrm{A}}(\%)=\left(\frac{\mathrm{CDI}_{\mathrm{T}}-\mathrm{CDI}_{\mathrm{A}}}{\mathrm{CDI}_{\mathrm{T}}}\right) * 100
$$

Individual increments in the $\mathrm{CDI}_{\mathrm{T}}$ were then averaged for the total number of respondents in every district. As a result, the district-wise average percent increment in $\mathrm{CDI}_{\mathrm{T}}$ of $\mathrm{PM}_{2.5}$ and $\mathrm{PM}_{10}$ were obtained separately from NAAQS and WHO ambient air quality standards respectively (Supplementary Annexure IV).

The normalization of dataset was a prerequisite before aggregating the indicators score, as many indicators were in different measurement units (Supplementary Annexure III). Therefore, the ' $\max -\min$ method' was used for making the various components unit less ${ }^{15,26}$.

An online expert survey was conducted based on a five-point Likert scale, and the scores assigned ranged from 'no importance' to 'very high importance'. The weighted average (based on the number of respondents) of the scores was done to deduce the weights for components and their respective indicators (online experts' names are presented in Supplementary Annexure II). The selection of experts was done based on the published literature available online in the domain of health and vulnerability assessment based on air pollution. Priority was given to authors having at least two publications in air pollution-related studies in a reputed journal.

The weights were then multiplied with the normalized values of indicators obtained by an equation followed by the linear aggregation of scores obtained for all the components ${ }^{15}$ as per the formula

$$
I=\sum_{i=1}^{N} W_{i} X_{i}
$$

where $X_{i}$ is the normalized variable, $W_{i}$ the weight attached to it and $i$ is the composite value of the indicator.

A district's final vulnerability score is the linear addition of total score by emission load, exposure, land useland cover (except forest cover score), sensitivity, and linear subtraction of total score by forest cover, and coping capacity ${ }^{15}$

An integrated framework for vulnerability assessment of air pollution-related health impacts includes five major components: emission load, exposure, land use-land cover, sensitivity and coping capacity, and followed by respective indicators, as well as sub-indicators (Figure 2). The logical reasoning and justification behind the selection of a specific component or indicator are shown in Table 1 .

Allocation of weights to the components, their indicators, and sub-indicators was an indispensable part of calculating vulnerability in the present study. Therefore, in accordance with the expert opinion from across the globe (Supplementary Annexure VI), emission load was rated highest (4.8). This may be due to the presence of emission sources at people's workplaces or at residences that exposed them more than otherwise. Further, emission load included three pollutants: $\mathrm{PM}_{2.5}, \mathrm{PM}_{10}$ and $\mathrm{NO}_{x}$ with $40 \%$ (1.9), 30\% (1.4) and 30\% (1.4) importance of total weightage (4.8) respectively. Following the emission load, exposure (4.6) and sensitivity (4.6) of people towards air pollutants were the experts' confounding factors. This was because the exposure of people to air pollutants varied with their age (children (3-11 years), adolescents (11-21 years), adults (21-61 years), elderly (>61 years), and microenvironment (home, transit and workplace)). Therefore, exposure component was further subdivided into two parts, viz. percentage increment of daily chronic intake in all the four age groups and the number of houseless family per 1000 households, with $80 \%$ (3.7) and $20 \%$ (0.9) share of total (4.6) weights respectively. The sensitivity component includes a specification section of individuals (children $(<19)$ and elderly group (>64)), and the prevalence rate of air pollutionrelated health problems (respiratory and cardiovascular). 


\section{RESEARCH COMMUNICATIONS}

Table 1. Summary of the identified components and indicators with the rationale

\begin{tabular}{|c|c|c|}
\hline Component & Indicator & Rationale \\
\hline Emission load & $\begin{array}{l}\text { Emission load of } \mathrm{PM}_{2.5} \\
\text { Emission load of } \mathrm{PM}_{10} \\
\text { Emission load of } \mathrm{NO}_{\mathrm{x}}\end{array}$ & $\begin{array}{l}\text { Investigation of the spatial distribution of emission load over a region } \\
\text { can help identify the vulnerability level of the exposed population if } \\
\text { their workplace or area of residence coincides with the relatively } \\
\text { higher range of emissions }{ }^{18} \text {. } \\
\text { Sources of emissions of } \mathrm{PM}_{2.5} \text { and } \mathrm{NO}_{\mathrm{x}} \text { and } \mathrm{PM}_{10} \text { are at the onset stage of } \\
\text { the chain causing air pollution health impacts, which can be locally } \\
\text { targeted for reducing vulnerability especially in high emission areas } \\
\text { having high population density }\end{array}$ \\
\hline \multirow[t]{2}{*}{ Exposure } & $\begin{array}{l}\text { Percentage increment in the calculat- } \\
\text { ed chronic daily intake }\left(\mathrm{CDI}_{\mathrm{T}}\right) \text { from } \\
\text { the acceptable chronic daily } \\
\text { intake }\left(\mathrm{CDI}_{\mathrm{A}}\right) \text { (WHO, NAAQS) } \\
\text { in children ( } 3 \text { to }<11 \text { years), } \\
\text { adolescents }(11 \text { to }<21 \text { years), } \\
\text { adults }(21 \text { to }<61 \text { years) and } \\
\text { elderly (above } 61 \text { years) }\end{array}$ & $\begin{array}{l}\text { CDI takes into account differential exposure with time-activity patterns } \\
\text { in micro-environments in terms of the daily dose of inhaled per kg of } \\
\text { body weight over a lifetime. } \\
\text { Children and the elderly are observed to have higher CDI values as } \\
\text { compared to adults; hence CDI is useful for determining age-related } \\
\text { vulnerability to air pollution concerning exposure }{ }^{27} \text {. }\end{array}$ \\
\hline & $\begin{array}{l}\text { Exposure due to housing } \\
\text { characteristics (number of } \\
\text { houseless family per } 1000 \\
\text { households) }\end{array}$ & $\begin{array}{l}\text { Deprived communities living in the open, roadside, under flyovers are } \\
\text { directly exposed to the vehicular pollution }{ }^{7} \text {. }\end{array}$ \\
\hline \multirow[t]{3}{*}{$\begin{array}{l}\text { Land use-land } \\
\text { cover features }\end{array}$} & $\begin{array}{l}\text { Number of industrial area in each } \\
\text { district }\end{array}$ & $\begin{array}{l}\text { The presence of industrial sites increases the health risks to the population } \\
\text { of nearby residential areas by degradation in air quality }{ }^{18} \text {. }\end{array}$ \\
\hline & $\begin{array}{l}\text { Number of construction and } \\
\text { demolition sites in each district }\end{array}$ & $\begin{array}{l}\text { Urban redevelopment planning to boost infrastructure for meeting demands } \\
\text { of growing population increases the construction, demolition activities } \\
\text { posing health risks due to dust, } \mathrm{PM}_{10}, \mathrm{PM}_{2.5} \text { in the workers involved in } \\
\text { the sites, and in the residents of nearby areas }{ }^{18} \text {. }\end{array}$ \\
\hline & Forest cover in each district & $\begin{array}{l}\text { Forests are biological filters for air pollutants, and dry deposition on leaves } \\
\text { reduces public health vulnerability to air pollution }{ }^{24} \text {. }\end{array}$ \\
\hline \multirow[t]{3}{*}{ Sensitivity } & $\begin{array}{l}\text { \% population of age groups } \\
\text { (<19 years }),(>64 \text { years })\end{array}$ & $\begin{array}{l}\text { Undeveloped lung functions, mouth breathing, immature immune systems } \\
\text { in children and high inhalation rate/body weight ratio make them more } \\
\text { sensitive to air pollution health risks as compared to adults }{ }^{27,30} \text {. The } \\
\text { elderly are also more sensitive to air pollution health risks due to the } \\
\text { decreased capability of defense immune systems }{ }^{27,30} \text {. }\end{array}$ \\
\hline & $\begin{array}{l}\text { Prevalence rate of respiratory and } \\
\text { cardiovascular diseases (acute } \\
\text { and chronic) }\end{array}$ & $\begin{array}{l}\text { Pre-existing comorbidity of respiratory and cardiovascular diseases } \\
\text { increases susceptibility generating a greater response to air pollution } \\
\text { as compared to the group with better health status }{ }^{6} \text {. }\end{array}$ \\
\hline & $\begin{array}{l}\text { Number of cases/total surveyed } \\
\text { population }\end{array}$ & $\begin{array}{l}\text { People with chronic diseases are perceivably more sensitive and affected } \\
\text { in terms of greater health risk outcomes associated with even short-term } \\
\text { exposure to air pollutants }{ }^{12} \text {. }\end{array}$ \\
\hline \multirow[t]{4}{*}{ Coping capacity } & $\begin{array}{l}\text { Access to health care facilities } \\
\text { (Number of functional beds/ } \\
\text { total population) per million }\end{array}$ & $\begin{array}{l}\text { Better infrastructure facilities in hospitals enhance the capacity of } \\
\text { people to recover from health effects of air pollution }{ }^{31,32}\end{array}$ \\
\hline & $\begin{array}{l}\text { Awareness of Govt initiatives to } \\
\text { curb air pollution }(\%) \\
(\text { Yes }=1, \text { No }=0)\end{array}$ & $\begin{array}{l}\text { A high awareness profile regarding government initiatives in a community } \\
\text { enhances the capacity to cope with their likely chances of participation in } \\
\text { activities reducing air pollution. }\end{array}$ \\
\hline & $\begin{array}{l}\text { Literacy rate (total literate } \\
\text { population aged } 7 \text { years or } \\
\text { above) }\end{array}$ & $\begin{array}{l}\text { The literate population has a higher coping capacity because they are in a } \\
\text { better position to understand health guidance compared to the illiterate } \\
\text { population }{ }^{5} \text {. }\end{array}$ \\
\hline & $\begin{array}{l}\text { Monthly household income } \\
\quad(<20 \mathrm{k}, 20 \mathrm{k}-50 \mathrm{k})\end{array}$ & $\begin{array}{l}\text { People with low socio-economic status are less likely to afford air } \\
\text { conditioners and air filters, which decreases their coping capacity } \\
\text { in case of air pollution episodes }{ }^{5,14} \text {. }\end{array}$ \\
\hline
\end{tabular}

Both the indicators were given equal weightage (2.34) by the experts out of the total sensitivity component weightage (4.6). Additionally, the health status indicator was divided into two sub-indicators (chronic and acute) into a $2: 3$ ratio of 2.34 , and age was also divided into two subindicators of equal ratio $(1: 1)$ (children $(<19)$ and elderly $(>64)$ ). The other two remaining components (land use-land cover and coping capacity) were rated as least important in assessing vulnerability with 3.6 weightage each. Land use-land cover was further categorized into three indicators (presence of industries, forest cover and construction site) with $35 \%(1.3), 30 \%(1.1)$ and $35 \%$ (1.3) of total weightage 3.6 respectively. Interestingly, presence of forest cover in an area reduces air pollutant impact on humans. Therefore, the values of forest cover were deducted from the final vulnerability score. Lastly, 


\section{RESEARCH COMMUNICATIONS}

coping capacity was included in the framework to understand the ability of an individual to overcome the air pollution-related health impact. Therefore, this component was subtracted from the vulnerability score. It was subdivided into four categories - health care facilities/ number of beds per million population, awareness of government initiatives, literacy rate, and monthly household income - with $30 \%$ (1.1), 20\% (0.7), 20\% (0.7) and $30 \%$ (1.1) of total coping capacity component weightage (3.6) respectively.

Results from vulnerability scores clearly showed differential vulnerability levels of the population residing in the selected district. A maximum vulnerability score of 1796.77 was obtained for East Delhi (Figures $3 d$ and 4). While analysing the scores obtained for the various components, we observed that the maximum contributing factor for vulnerability of East Delhi was the increment in CDI from the acceptable CDI for $\mathrm{PM}_{2.5}$ and $\mathrm{PM}_{10}$ (Figures $3 b$ and 4) (Supplementary Annexure V). This can be attributed to higher concentrations of particulate matter due to the presence of bus and railway stations in the vicinity of residential areas observed during the pilot study. Also, negating components in vulnerability assessment such as percentage of geographical area under forest cover has been least reported $(5.13 \%)$ in East Delhi compared to other districts (Figures $3 b$ and 4 ).
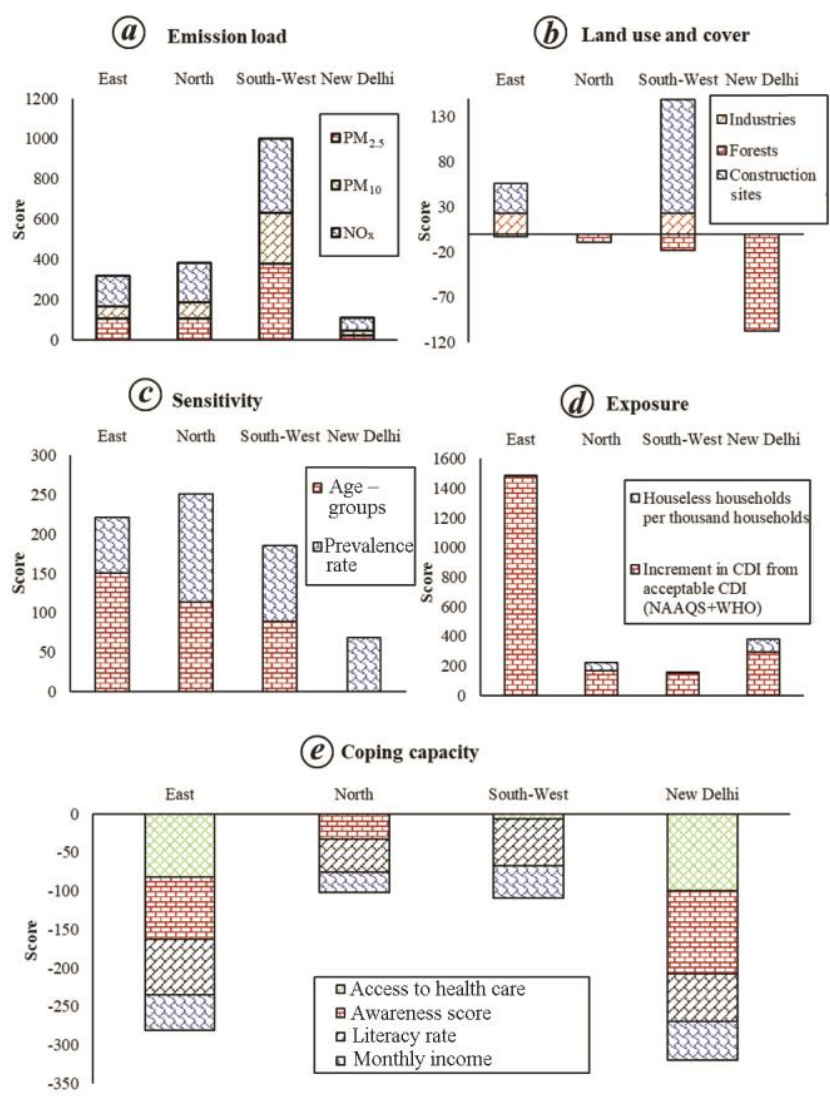

Figure 3. Component-wise vulnerability score. $\boldsymbol{a}$, Emission load; $\boldsymbol{b}$, Land use-land cover; $\boldsymbol{c}$, Sensitivity; $\boldsymbol{d}$, Exposure; $\boldsymbol{e}$, Coping capacity.
However, the coping capacity score of East Delhi (highest vulnerability score) is comparable to New Delhi (lowest vulnerability score) (Figures $3 e$ and 4) which dilutes the negating effect in the total score. New Delhi has scored a least vulnerability score of 131.45 (Figures 4 and 5). Even though the exposure component of East Delhi and New Delhi has a relatively higher score as compared to that of South-West Delhi and North Delhi, which are more vulnerable as per the scores, the effect of exposure is not enhanced due to lower scores for other contributing components towards vulnerability, such as the sensitivity; presence of industries, construction, and demolition sites; and emission load. In addition, negating factors like geographical area under forest cover and coping capacity have maximum values which overall contribute to the least relative vulnerability score.

Exposure cycle assessment results showed that in all the age groups surveyed, values for calculated CDI were beyond the acceptable CDI (reported as average per cent increment), which was also reported by earlier researchers $^{1,4}$ (Supplementary Annexure IV). The increments were observed to be highest in elderly age groups, followed by children indicating that age is an important factor for differential exposure levels in a population ${ }^{27}$. Therefore, it can be deduced that the impact of air pollution

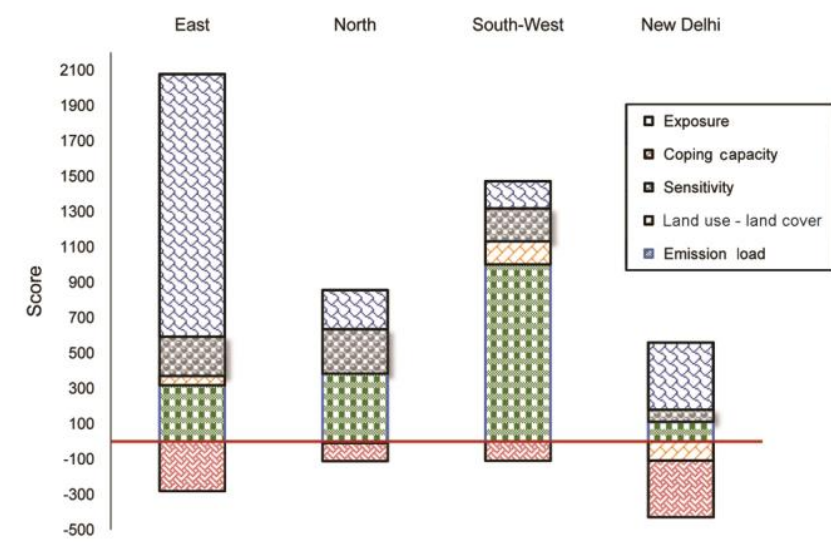

Figure 4. District and component-wise vulnerability score.

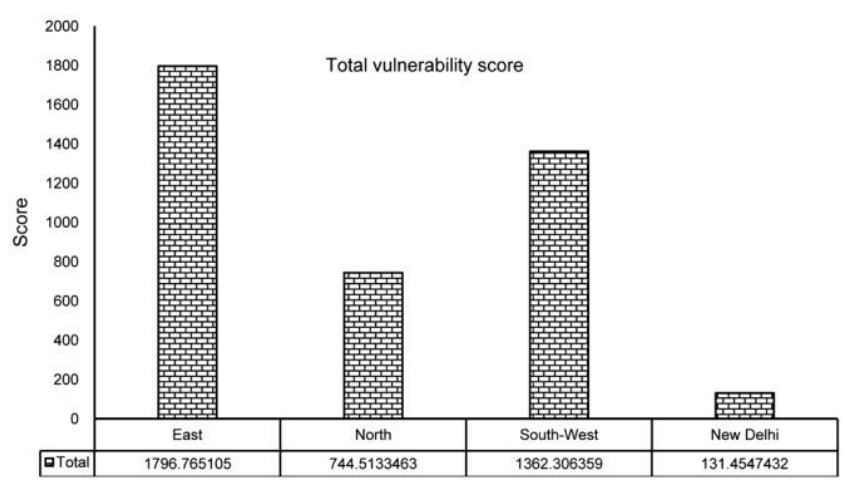

Figure 5. Vulnerability score of the district.

CURRENT SCIENCE, VOL. 120, NO. 6, 25 MARCH 2021 


\section{RESEARCH COMMUNICATIONS}

may have an adverse effect on the population, but the individual is expected to react indifferently to the vulnerability of air pollution ${ }^{28,29}$

The present (pilot) study's proposed framework clearly shows that the identified components - emission load, exposure, sensitivity, coping capacity and land use-land cover features contribute differentially to vulnerability levels in the study area. Hence, an integrated vulnerability assessment delivers comprehensive details about relative vulnerability through critical insights on the contributing and negating indicators. The results of our study show that East Delhi is the top vulnerability scorer, further intensified by the fact that the region has the secondhighest population density in Delhi. Hence populations at risk in East Delhi are deemed to be prioritized; especially the vulnerable sub-groups in any implementation of health-risk mitigation or air quality management policies, so that they are benefited more in terms of risk reductions.

The proposed framework can be applied for detailed assessment of vulnerability to health effects of air pollution within a district or can be used to deduce interdistrict inferences by identifying high-risk areas after the data gaps are filled by either secondary data sources or by self-reported site visits and surveys. However, based on area and requirement of the study, the developed framework can be modified for more precise result in both intra or inter district assessments. For instance, an addition of indicators like occupational exposures (traffic policemen, toll plaza workers, workers involved in construction and demolition activities, petrol pump workers), type of area of residence (commercial, residential, semicommercial, industrial), and its proximity to heavy traffic could also be clubbed in the present framework for the more elaborative results.

The present study can be carried out for assessment in different cities as well, if the possible research avenues are to assess the level of vulnerability in most polluted Indian cities or to conduct comparative assessment between least polluted and most polluted cities. In such cases, the framework will then have explicit extensions in meteorology parameters and topography features. Vulnerability mapping can also be employed to enhance visual representation and communication of assessment results. On the whole, the framework's true essence will be realized if there is a nexus between the planning stage of intervention schemes and policies aimed to deliver outcomes as public health benefits through reduction in air pollution levels.

Declaration: There is no conflict of interest between the authors.

1. Aggarwal, P. and Jain, S., The impact of air pollutants from surface transport sources on human health: A modeling and epidemiological approach. Environ. Int., 2015, 83, 146-157.
2. Brauer, M. et al., Ambient air pollution exposure estimation for the global burden of disease 2013. Environ. Sci. Technol., 2016, 50(1), 79-88.

3. Jain, S. and Khare, M., Urban air quality in megacities: a case study of Delhi city using vulnerability analysis. Environ. Monit. Assess., 2008, 136(1-3), 257-265.

4. Kumar, P., Jain, S., Gurjar, B. R., Sharma, P., Khare, M., Morawska, L. and Britter, R., Can a 'Blue Sky' return to Indian megacities? Atmos. Environ., 2013, 71, 198-201.

5. Gurjar, B. and Nagpure, A., Indian megacities as localities of environmental vulnerability from air quality perspective. J. Smart Cities, 2015, 1, 15-30; doi:10.18063.

6. Banerjee, M., Siddique, S., Mukherjee, S., Roychoudhury, S., Das, P., Ray, M. R. and Lahiri, T., Hematological, immunological, and cardiovascular changes in individuals residing in a polluted city of India: a study in Delhi. Int. J. Hyg. Environ. Health, 2012, 215(3), 306-311.

7. Holgate, S. T., Every breath we take: the lifelong impact of air pollution - a call for action. Clin. Med., 2017, 17(1), 8 .

8. Lim, S. S. et al., A comparative risk assessment of burden of disease and injury attributable to 67 risk factors in 21 regions, 19902010: a systematic analysis for the Global Burden of Disease Study 2010. Lancet, 2012, 380, 2224-2260.

9. Gadhok, T. K., Risks in Delhi: Environmental concerns. In Geospatial World, 2011.

10. Cropper, M. L., Simon, N. B., Alberini, A. and Sharma, P. K., The health effects of air pollution in Delhi, India. Policy Research Working Papers No. 1860, The World Bank, Washington, DC, 1997.

11. Pande, J. N., Bhatta, N., Biswas, D., Pandey, R. M., Ahluwalia, G., Siddaramaiah, N. H. and Khilnani, G. C., Outdoor air pollution and emergency room visits at a hospital in Delhi. Indian J. Chest Dis. Allied Sci., 2001, 44, 13-19.

12. Jayaraman, G. N., Air quality and respiratory health in Delhi. Environ. Monit. Assess., 2007, 135(1-3), 313-325.

13. Siddique, S., Banerjee, M., Ray, M. R. and Lahiri, T., Air pollution and its impact on lung function of children in Delhi, the capital city of India. Water, Air and Soil Pollut., 2010, 212(1-4), 89-100.

14. Singh, A. L. and Jamal, S., Indoor air pollution: types of cooking fuel used and its impact on the health of women in Aligarh city. Int. J. Environ. Health, 2011, 5(3), 205-220.

15. Nardo, M., Saisana, M., Saltelli, A., Tarantola, S., Hoffman, H. and Giovannini, E., Handbook on Constructing Composite Indicators: Methodology and User Guide. OECD Statistics Working Paper, 2005; www.olis.oecd.org/olis/2005doc.nsf/LinkTo/std-doc

16. Wright, C. Y. and Diab, R., International perspectives: air pollution and vulnerability: solving the puzzle of prioritization. J. Environ. Health, 2011, 73(6), 56-64.

17. Samet, J. M., Some current challenges in research on air pollution and health. Salud Pública México, 2014, 56(4), 379-385.

18. Sharma, M. and Dikshit, O., Comprehensive study on air pollution and Green House Gases (GHGs) in Delhi (Indian Institute of Technology, Kanpur). A report submitted to Government of NCT Delhi and DPCC Delhi, 2016, pp. 1-334.

19. Chandramouli, C. and General, R., Provisional Population Totals, Paper 1 of 2011, India, Series 1. Office of the Registrar General and Census Commissioner, India, 2011, p. 188; www.censusindia. gov.in/2011-prov-results/prov_results_paper1_india.html

20. Annual Report, Directorate General of Health Services, Government of National Capital Territory of Delhi, 2015, pp. 156-184.

21. World Health Organization (WHO), Health aspects of air pollution: results from the WHO project 'Systematic review of health aspects of air pollution in Europe' (No. EUR/04/5046026). WHO Regional Office for Europe, Copenhagen, 2004.

22. World Health Organization (WHO), WHO Global Urban Ambient Air Pollution/Database, 2016; www.who.int/phe/health_topics/ outdoorair/databases/cities/en/ 
23. CPCb.GOV.IN/CAAQM/frmUserAvgReportCriteria.aspx

24. ISFR, India State of Forest Report. Forest Survey of India, Ministry of Environment Forest and Climate Change, Government of India, Dehra Dun, 2015.

25. USEPA (United State Environmental Protection Agency), Exposure Factors Handbook, 2011.

26. Munda, G., 'Measuring sustainability': a multi-criterion framework. Environ. Dev. Sustain., 2005, 7(1), 117-134.

27. Bateson, T. F. and Schwartz, J., Children's response to air pollutants J. Toxicol. Environment. Health, Part A, 2007, 71(3), 238-243.

28. Makri, A. and Stilianakis, N. I., Vulnerability to air pollution health effects. Int. J. Hygiene Environ. Health, 2008, 211(3-4), 326-336.

29. Stilianakis, N. I., Susceptibility and vulnerability to health effects of air pollution: The case of nitrogen dioxide. Joint Research Centre, European Commission, 2015.

30. Burri, P. H., Fetal and postnatal development of the lung. Ann. Rev. Physiol., 1984, 46, 617-628.

31. Garg, A., Pro-equity effects of ancillary benefits of climate change policies: A case study of human health impacts of outdoor air pollution in New Delhi. World Dev., 2011, 39(6), 1002-1025.
32. Kwatra, S., Kumar, A., Sharma, P., Sharma, S. and Singhal, S., Benchmarking sustainability using indicators: an Indian case study. Ecol. Indic., 2016, 61, 928-940.

33. Feigin, V. L. et al., Global burden of stroke and risk factors in 188 countries, during 1990-2013: a systematic analysis for the Global Burden of Disease Study 2013. Lancet Neurol., 2016, 15(9), 913 924.

ACKNOWLEDGMENT. We are grateful to our mentor Dr Suresh Jain for his constant guidance and motivation throughout the study. We also acknowledge our fellow senior Ms Tanya, Ms Nishi and Dr Naveen C. Joshi for their critical insights to improve upon this manuscript. We also acknowledge all the volunteers for their valuable time and effort to conduct field date for the study.

Received 19 January 2021; revised accepted 3 February 2021

doi: $10.18520 / \mathrm{cs} / \mathrm{v} 120 / \mathrm{i} 6 / 1092-1098$ 